\title{
Characteristics of Hydro-geochemictry and Its Zoning in Hai Duong Urban Area
}

\author{
Nguyen Van Dan ${ }^{1, *}$, Hoang Van Duy², Van Thuy Linh ${ }^{3}$, Tran Duy Hung ${ }^{4}$ \\ ${ }^{1}$ Hydrogeological Association of Viet Nam, 10 Tran Cung, Cau Giay, Hanoi, Vietnam \\ ${ }^{2}$ Northern Division for Water Resources Planning and Investigation, 10 Tran Cung, Hanoi, Vietnam \\ ${ }^{3}$ Institute of Resources, Environment and Sustainable Development (IRED), \\ 114 Tran Duy Hung, Hanoi, Vietnam \\ ${ }^{4}$ Department of Water Resources Management, 10 Ton That, Thuyet, Cau Giay, Hanoi, Vietnam
}

Received 07 December 2018

Revised 14 December 2018; Accepted 14 December 2018

\begin{abstract}
Hai Duong urban area consists of Hai Duong city and its vicinity, covering an area of about $500 \mathrm{~km}^{2}$, located in the center of the Red River Delta with three main aquifers: qh, qp and $\mathrm{n}$. The (qp) and (n) aquifers have significant amount of water potential, meaning that they can be sources for public water supply, but poor water quality that can limit the meaning of water supply. Highlights of water quality are: high level of total dissolved solid, iron content, manganese and nitrogen compounds. In all three aquifers water is saline in most of the area, accounting for $22 \%$ to $64 \%$ of the area. The risk of salinity intrusion can be happened in all aquifers. For the (qp) aquifer, forecast to 2030, under current water exploitation conditions, salinity intrusion rates may range from 2.7 to $9.3 \mathrm{~m}$ per year. In the study area, there are three types of hydro-geochemistry: Type I - All layers of water in the section are fresh; Type II - Top (qh) is fresh, (qp) and (n) aquifers are salinity, in which the (qp)is more salty than the (n) layer and the V-type is saline water in (qh) and (qp) aquifers, in the (n) aquifer water is fresh. The I type is normal of hydro-geochemistry; The $\mathrm{V}$ type is inverseof hydro-geochemistry due to (n) aquifer which its recharge is far from. In the II type there are both normal and invers of hydro-geochemistry due.
\end{abstract}

Keywords: Water quality, aquifer, hydro-geochemical zoning, salinity intrusion.

Studying hydro-geochemical characteristics and its distribution is very important for determining the purpose of water use and the origin of groundwater formation. However, in

\footnotetext{
*Tác giả liên hệ. ĐT.: 84-913239209.

Email: nguyenvandan1950@yahoo.com

https://doi.org/10.25073/2588-1094/vnuees.4347
} 
our country this research is often associated with the general study of groundwater. One of the special researches on hydro-geochemical analysis is the work of Nguyen Van Dan [4], after evaluating the overall hydro-geochemical characteristics of coastal areas from Mong Cai to Ha Tien, He made a zoning map for the hydrogeochemistry, which is basics for forecasting for the presence of fresh groundwater in some coastal offshore areas

In Hai Duong area, the hydro-geochemistry is rather complicate, the research results showed that there is intercalation between fresh water layer and saline water layer in the profile requires intensive research. Based on the water resource investigation and assessment report, the Hai Duong urban geological survey report and the recent survey on water protection in Hai Duong urban area in period 2014-2018, Hoang Van Duy [2] had the thesis for Master of science in the research on hydro-geochemistry. This article, publishes the results of Hoang Van Duy's research. And on the other hand, there is showing additional research results on the basis of application of integrated methods, system analysis, GIS and numerical modeling methods to simulate conditions, process and prediction of salinity intrusion with specialized softwares such as GMS, Modflow, MT3D...

\section{Introduce the research area}

The study area covers the whole acreage of Hai Duong city and part of the area of the districts of Nam Sach, Thanh Ha, Cam Giang, Gia Loc (Hai Duong province), Van Lam, My Hao (Hung Yen province), Thuan Thanh, Gia Binh (Bac Ninh province) located in the center of the Northern Delta, Area of about $500 \mathrm{~km}^{2}$ (Figure 5) has a relatively flat topography with a height of 2-6 m, has tropical monsoon climate, the year is divided into two distinct seasons. The cold season coincides with the rainy less season from November to April of the following year, the hot season coincides with the rainy season from May to October with $80 \%$ of the annual rainfall. Average annual rainfall is $1533 \mathrm{~mm}$. In the rainy season, the rainfall is much higher than the evaporation is the "moisture redundancy" period; In the dry season, evaporation is greater than rainfall, which is the period of "moisture shortage" (Figure 1).

The research area has a system of dense rivers including big rivers such as Thai Binh, Pha Lai, Duong, Kinh Thay... Northwest - Southeast direction and have hydrological regime that repeats the rain regime: Flood season from May to October, The dry season from November to April next year.

Due to the phasing of the sediment, the researchers divided into three aquifers: holes of Holocene sediment layer, denoted by (qh), holes of Pleistocene sediment layer, denoted by (qp), and the fractured - holes aquifer of Neogene sediment layer, denoted by (n). Between them are clay formations, sandy silt permeability weak (Figure 2).

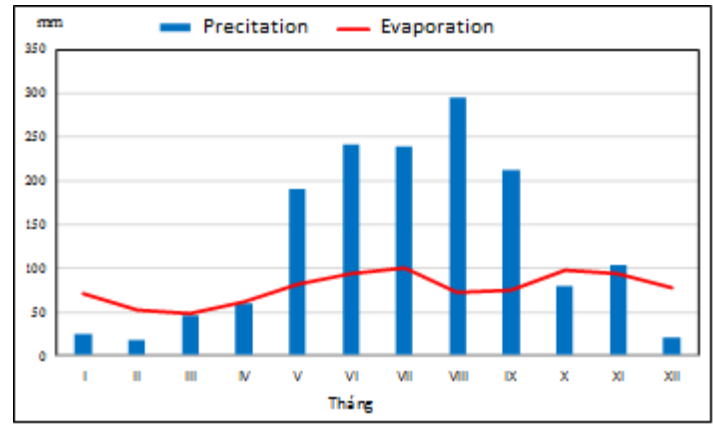

Figure 1. The annual precitationand evaporation at Hai Duong station. 


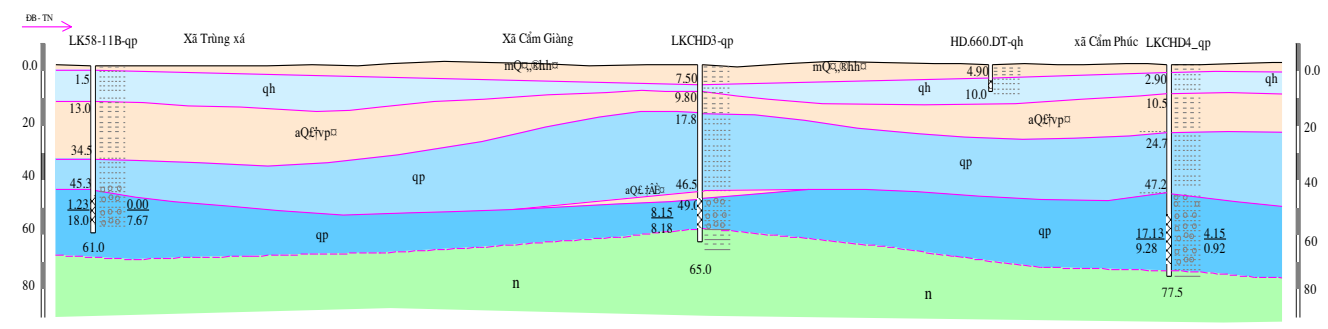

Figure 2. Hydrogeological section across the study area.

Holocene (qh) aquifer the no pressure layer on the top of the section, exposed on the surface, Widely distributed throughout most of the study area. The soil and rock composition is fine sand containing less gray clay, thickness of $0.5-30 \mathrm{~m}$, average $8.3 \mathrm{~m}$. Static water levels vary from 0.5 $\mathrm{m}$ to $1.65 \mathrm{~m}$ above the ground, flow of boreholes is ranging from very small to $71 / \mathrm{s}$. Water conductivity varies from 180 to $2260 \mathrm{~m}^{2} /$ day, The water level of the aquifer is poor to medium, meaning only small supply.

Pleistocene ( $q p$ ) aquifer widely distributed throughout the study area but completely covered by (qh) aquifer. Composition of rocky soil consists of 2 parts, the upper part is medium to fine quartz sand of VinhPhuc formation, the lower part consists of pebbles, sand, gravel of the Hanoi Formation. Between them there are clay layers are not continuous, so there is general pressure. The thickness varies from $13 \mathrm{~m}$ to $81 \mathrm{~m}$, average $40 \mathrm{~m}$. Water of the aquifer has pressure with pressure column of about $25-45 \mathrm{~m}$, Water often appears at a depth of $30-50 \mathrm{~m}$ and is stable at a depth of $3.5-5.0 \mathrm{~m}$ above the ground. Flow of boreholes experiment modified from 81/s to 541/s corresponding to the water level drops from $0.5 \mathrm{~m}$ to $5.5 \mathrm{~m}$. Water conductivity varies from 1426 to $3224 \mathrm{~m}^{2} /$ day. The (qp) aquifer is rich in water, means supply focus, but the scale is not large because most of the aquifer area is salty.

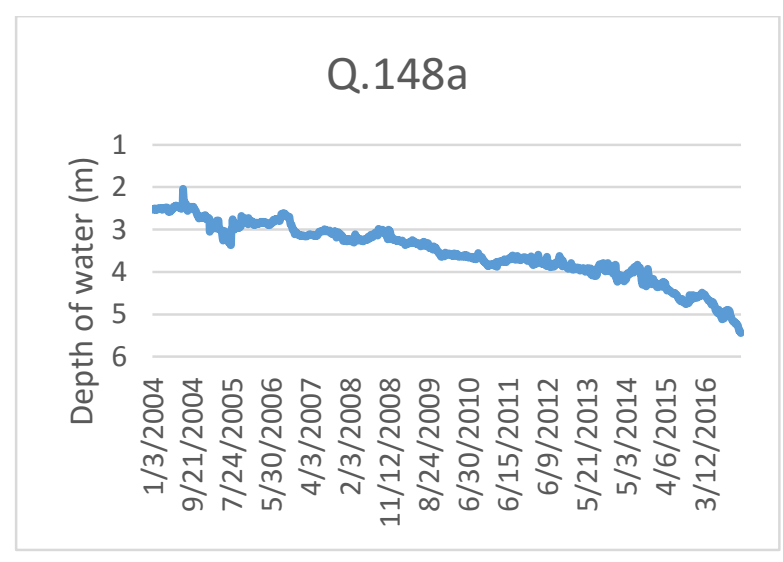

Pleistocene (qp) aquifer- Q.148a

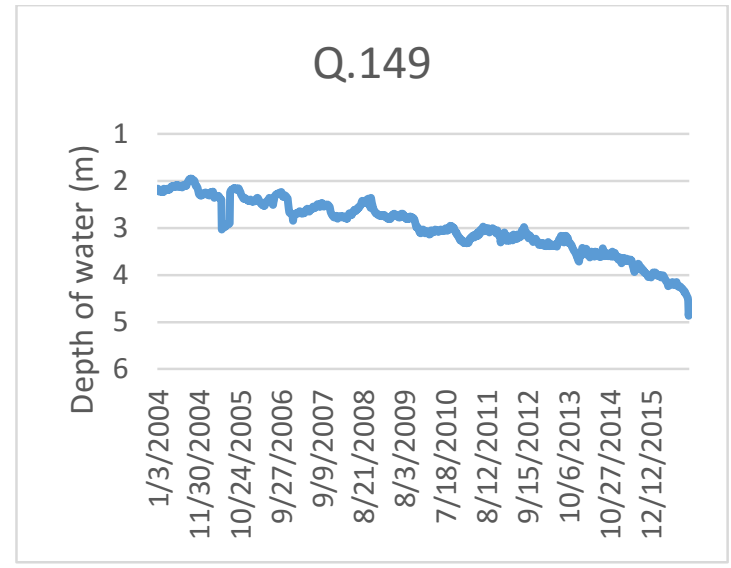

Neogene (n) aquifer- Q.149

Figure 3. Ground water level of Hai Duong Urban. 
The fractured-holes aquifer of Neogene sediment layer $(n)$ includes the formation of a division system of the Vinh Bao and Tien Hung formation wide distributed, It covers the entire study area but does not expose on the surface. Due to the level of research of this stratum is sketchy should be placed in a aquifer. Composition of rocky soil includes sandstone, the pebble interbedded clay layers with weak bonding levels encountered at a depth of 67-135 $\mathrm{m}$, thickness of the (n) aquifer from 22 to $>200 \mathrm{~m}$, Water in the (n) aquifer has pressure with pressure column up to $>100 \mathrm{~m}$. Static water is located at a depth of $2.0 \mathrm{~m}$ to $4.87 \mathrm{~m}$ above the ground, flow of boreholes experiment varies from 5.41/s to 231/s. The (n) aquifer is classified as rich in water and meaningful focus on water supply, however, due to the large area of salt water, the meaning of water supply is limited.2. Situation of underground water exploitation

The research area has a high demand for water, but the exploitation of underground water is very limited. The only concentrated mining project in Cam Giang that supplies water to Hai Duong City has ceased its operation due to water quality problems. There are only two forms of water exploitation: "single water exploitation " and "rural water exploitation ". "Single water exploitation" means the exploitation and supply of water from factories, enterprise... In the area with intermittent mining regime, depending on production requirements, average 6 to 8 hours per day. When implementing the project "Underground water protection in Hai Duong urban area", The Northern Water Resources Planning and Investigation Division has surveyed, statistics of the number of wells exploited in this area is 190. Exploitation of (qp) aquifers and (n) with a total discharge of 25,000 $\mathrm{m}^{3} /$ day.

"Rural water exploitation" is a type of exploitation by small diameter boreholes, wells used for water supply to households. When implementing the project mentioned above, The Northern Water Resources Planning and Investigation Division has surveyed, statistics are about 37,000 dug wells and 130,000 small diameter wells in the study area, mainly exploited (qh) aquifer and the upper part of the (qp) aquifer.

\section{Characteristics of chemical hydrogeology}

\subsection{TDS and chemical composition}

TDS and the chemical composition of the aquifers have the following characteristics [2].

TDS and chemical composition of the (qh) aquifer was studied at 56 water points shows that: in the North West - Southeast direction, the TDS of water increase, changes from super fresh to salinity. Salinity water area (TDS $<1000 \mathrm{mg} / \mathrm{l})$ distributed in the northwest with an area of 380 $\mathrm{km}^{2}$ Water of a complex chemical form: sodium bicarbonate, calcium bicarbonate or calcium chloride bicarbonate; Salt water with TDS ranges from $1000-3000 \mathrm{mg} / \mathrm{l}$ is distributed in the southeast with an area of $110 \mathrm{~km}^{2}$ is the major chemical type Sodium - Chloride.

The $\mathrm{pH}$ of groundwater varies considerably from 4.40 to 9.59; Water is weak acid to alkaline.

Ion $\mathrm{Cl}^{-}$varying from 11.5 to 2330.8 ; average $317.0 \mathrm{mg} / \mathrm{l}$. The majority of research samples, ion $\mathrm{Cl}^{-}$occupy mainly in percentage of equivalents, has a sample of $90 \%$; followed by $\mathrm{HCO}_{3}$ - followed by $\mathrm{SO}_{4^{-}}{ }^{2}$;ion $\mathrm{CO}_{3}{ }^{-}$is almost absent in water.

Ion $\mathrm{Na}^{+}$varies from 41 to 1450 ; average $181.8 \mathrm{mg} / \mathrm{l}$. Most of the $\mathrm{Na}^{+}$ion research samples are predominantly in the equivalent percentages, samples reached $89 \%$, followed by $\mathrm{Mg}^{+2}$, followed by $\mathrm{Ca}^{+2}$

TDS and chemical composition of the (qp)aquifer was studied at 86 water points shows that: in the North West - Southeast direction and North - South direction, TDS of water increase, changes from super fresh to salinity. Salinity water area (TDS $<1000 \mathrm{mg} / \mathrm{l}$ ) is distributed in the northwest of Thuan Thanh district (Bac Ninh province), Van Lam district, My Hao district (Hung Yen province) and one part of Cam Giang district (Hai Duong province) with an area of 180 $\mathrm{km} 2$. Water has complex chemical form: 
bicarbonate-sodium, bicarbonate-sodium salt canxic or chloride - sodium or calcium chloridesodium. Salt water with TDS ranges from 1000$3000 \mathrm{mg} / \mathrm{l}$ is distributed in the southeast of Luong Tai district (Bac Ninh province), Nam Sach district, Thanh Ha district, Hai Duong province.

The $\mathrm{pH}$ of underground water varies from 4.5 to 8.16 ; water is weak to weak alkaline acids.

The ionic content of $\mathrm{Cl}^{-}$varies from 22 to $2680 \mathrm{mg} / \mathrm{l}$ and accounts for the equivalent percentage, have sample of $100 \%$, followed by $\mathrm{HCO}_{3}{ }^{2-}$, then $\mathrm{SO}_{4}{ }^{-2}$.

The $\mathrm{Na}^{+}$ion content varies from 4 to 765 $\mathrm{mg} / \mathrm{l}$ and predominates in equivalent percentages, have sample of $90 \%$, followed by $\mathrm{Ca}^{+2}$, then $\mathrm{Mg}^{+2}$.

TDS and chemical composition of the (n) aquifer was studied at 16 water points shows that: in the North West - Southeast direction, TDS of water varies from super fresh to salinity. Salinity water area (TDS $<1000 \mathrm{mg} / \mathrm{l}$ ) is distributed in the North West and part of Thanh Ha district with an area of $300 \mathrm{~km}^{2}$. Water has chemical types: bicarbonate - sodium bicarbonate, magnesium chloride - calcium magnesium calcium or chloride - sodium chloride, sodium chloride. Salt water with TDS ranges from $1000-7540 \mathrm{mg} / 1$ is distributed into the stretch from North East to Southwest with an area of $200 \mathrm{~km}^{2}$. Water has the chemical type chloride-sodium.

$\mathrm{pH}$ of groundwater varies from 5.0 to 7.15 ; Water is weak acid to neutral.

The $\mathrm{Cl}$ - ion content varies from 14 to 4433 $\mathrm{mg} / \mathrm{l}$ and accounts for most of the equivalent percentage, highest was $96 \%$, followed by $\mathrm{HCO}_{3}{ }^{2-}$, then $\mathrm{SO}_{4}^{-2}$.

The $\mathrm{Na}^{+}$content is from 20 to $2128 \mathrm{mg} / \mathrm{l}$ and accounts for most of the equivalent percentages, the highest is $80 \%$, followed by $\mathrm{Ca}^{+2}$, then $\mathrm{Mg}^{+2}$.

\subsection{Groundwater quality}

To assess groundwater quality, used QCVN 09-MT: 2015/BTNM with 32 parameters. However, as the research was only general, only
18 parameters were identified and focused only on the (qp) aquifer because of significant water supply results as shown in table 1 .

There are 9 parameters in excess of QCVN 09-MT: 2015 with the following comments:

- The $\mathrm{pH}$ was determined in 37 samples with results ranging from 4.5 to 8.16 , average 6.5 , of which one sample, accounting for $2.7 \%$ exceeding the allowed standard with a maximum value of 8.16 .

- TDS was determined in 37 samples with results ranging from 129 to 4793, an average of $1207 \mathrm{mg} / \mathrm{l}$, of which 9 samples, accounting for $24 \%$, exceeded the allowed standard with a maximum value of $4793 \mathrm{mg} / \mathrm{l}$, exceeding 3.2 times.

- Total iron was determined in 25 samples with results ranging from 0.1 to 41.53 , an average of $7.32 \mathrm{mg} / \mathrm{l}$, of which 20 samples, accounting for $40 \%$, exceeded the permitted standard with the maximum value of $41.53 \mathrm{mg}$ $/ 1$, exceeding 8.3 times.

- $\mathrm{NO}_{3}$ nitrate was determined in 9 samples with results ranging from 6.1 to 28.3 , an average of $14.56 \mathrm{mg} / \mathrm{l}$, of which 5 samples, accounted for $55 \%$, exceeded the allowed standard with the maximum value of $28.3 \mathrm{mg} / \mathrm{l}$, exceeded 1.9 times.

- Nitrite $\mathrm{NO}_{2}$ was determined in 9 samples with results ranging from 0.008 to 4.5 , an average of $0.52 \mathrm{mg} / \mathrm{l}$, of which one sample, accounting for $11 \%$, exceeds the allowed standard with a value of $4.5 \mathrm{mg} / \mathrm{l}$, exceeding 4.5 times.

- $\mathrm{NH}_{4}{ }^{+}$ammonium was determined in 9 samples with results ranging from 0.62 to 3.4 , an average of $1.5 \mathrm{mg} / \mathrm{l}$, of which 4 samples, accounting for $44 \%$, exceeding the allowed standard with the maximum value of $3.4 \mathrm{mg} / \mathrm{l}$, exceeding 3.4 times.

- Mn was determined in 10 samples with results ranging from 0.14 to $3 \mathrm{mg} / \mathrm{l}$. There are 7 samples, accounting for $70 \%$ exceeded the permitted standard with a maximum value of 3 $\mathrm{mg} / 1$, exceeding 6 times. 
Table 1. Evaluation of water quality in (qh) aquifer

\begin{tabular}{|c|c|c|c|c|c|c|c|c|c|}
\hline \multirow{2}{*}{ Order number } & \multirow{2}{*}{ Parameters } & \multirow{2}{*}{$\begin{array}{l}\text { Number } \\
\text { of } \\
\text { samples }\end{array}$} & \multicolumn{3}{|c|}{ Characteristic value } & \multirow{2}{*}{ Unit } & \multirow{2}{*}{$\begin{array}{l}\text { QCVN } \\
09-M T: \\
2015\end{array}$} & \multirow{2}{*}{$\begin{array}{l}\text { Number } \\
\text { of sample } \\
\text { exceeding } \\
\text { the } \\
\text { standard } \\
\end{array}$} & \multirow{2}{*}{$\begin{array}{l}\text { Proportion } \\
\%\end{array}$} \\
\hline & & & Min & Max & Average & & & & \\
\hline 1 & $\mathrm{pH}$ & 37 & 4.5 & 8.16 & 6.50 & & $5.5-8.5$ & 1 & 2.7 \\
\hline 2 & TDS & 37 & 129 & 4793 & 1207.87 & $\mathrm{mg} / \mathrm{l}$ & 1500 & 9 & 24.32 \\
\hline 3 & $\mathrm{Cl}^{-}$ & 37 & 22.16 & 2680.02 & 615.02 & $\mathrm{mg} / \mathrm{l}$ & 250 & 21 & 56.75 \\
\hline 4 & $\mathrm{SO}_{4}{ }^{2-}$ & 37 & 1.2 & 67.5 & 14.72 & $\mathrm{mg} / \mathrm{l}$ & 400 & & \\
\hline 5 & $\mathrm{NO}_{3}^{-}$ & 9 & 6.1 & 28.3 & 14.56 & $\mathrm{mg} / \mathrm{l}$ & 15 & 5 & 55.56 \\
\hline 6 & $\mathrm{NO}_{2}^{-}$ & 9 & 0.008 & 4.5 & 0.52 & $\mathrm{mg} / \mathrm{l}$ & 1 & 1 & 11.11 \\
\hline 7 & $\mathrm{NH}_{4}^{+}$ & 9 & 0.62 & 3.4 & 1.53 & $\mathrm{mg} / \mathrm{l}$ & 1 & 4 & 44.44 \\
\hline 8 & Total Iron & 25 & 0.1 & 92 & 16.46 & $\mathrm{mg} / \mathrm{l}$ & 5 & 11 & 44.00 \\
\hline 9 & As & 10 & 0.0007 & 0.17 & 0.01925 & $\mathrm{mg} / \mathrm{l}$ & 0.05 & 1 & 10 \\
\hline 10 & $\mathrm{Hg}$ & 10 & 0.0002 & 0.002 & 0.0009833 & $\mathrm{mg} / \mathrm{l}$ & 0.001 & & \\
\hline 11 & $\mathrm{Cr}$ & 10 & 0.0005 & 0.02 & 0.0037 & $\mathrm{mg} / \mathrm{l}$ & 0.05 & & \\
\hline 12 & $\mathrm{Cd}$ & 10 & 0.0004 & 0.001 & 0.0008 & $\mathrm{mg} / \mathrm{l}$ & 0.005 & & \\
\hline 13 & $\mathrm{~Pb}$ & 10 & 0.001 & 0.006 & 0.0018333 & $\mathrm{mg} / \mathrm{l}$ & 0.01 & & \\
\hline 14 & $\mathrm{Cu}$ & 10 & 0.001 & 0.007 & 0.0034286 & $\mathrm{mg} / \mathrm{l}$ & 1 & & \\
\hline 15 & $\mathrm{Zn}$ & 10 & 0.015 & 0.322 & 0.0574 & $\mathrm{mg} / \mathrm{l}$ & 3 & & \\
\hline 16 & $\mathrm{Mn}$ & 10 & 0.138 & 3 & 1.4264 & $\mathrm{mg} / \mathrm{l}$ & 0.5 & 7 & 70 \\
\hline 17 & $\mathrm{CN}^{-}$ & 10 & 0.001 & 0.005 & 0.002 & $\mathrm{mg} / \mathrm{l}$ & 0.01 & & \\
\hline 18 & Phenol & 10 & 0.001 & 0.01 & 0.006075 & $\mathrm{mg} / \mathrm{l}$ & 0.001 & & \\
\hline
\end{tabular}

- As was determined in 10 samples with results ranging from 0.0007 to 0.17 , an average $0.01925 \mathrm{mg} / \mathrm{l}$, of which one sample, accounting for $10 \%$, exceeds the permissible standard with a value of $0.17 \mathrm{mg} / \mathrm{l}$, exceeding 3.4 times.

The combined results show that outstanding water quality issues are TDS, iron, manganese, and nitrogen compounds. TDS increase, the researchers found that the seawater was formed during seawalls that had been salted during geologic seasons but was now at risk of salinisation due to water exploited. The rest of the increase is the expression of contaminated water, where the origin of contamination of nitrogen compounds, Nguyen Van Dan and Nguyen Thi Dung [3] argue that mainly due to human activities; The origin of iron and manganese pollution, Nguyen Kim Ngoc [1] due to nature.

\subsection{Situation of groundwater salinity intrusion}

Salty situation of groundwater. The combined results in section 3.1 above show that all aquifers in the study area are saline (TDS> $1000 \mathrm{mg} / \mathrm{l})$ The area is quite large, accounting for $22 \%$ of (qh) aquifer and $40 \%$ of (n) aquifer and $64 \%$ of (qp) aquifer.

Forecast for salinity intrusion of (qp) aquifer. For the prediction of groundwater salinity intrusion(qp), Hoang Van Duy [2] constructed the groundwater model using MODFLOW- MT3DMS software to determine the material movement in the mining conditions. Results showed that, by 2030, the fresh area of the (qp) aquifer was narrowed down. The boundary between salty and fresh is moved towards the mining area from 40 to $140 \mathrm{~m}$ compared to the current rate of $2.7-9.3 \mathrm{~m} /$ year (Table 2) 
Table 2. The speed of movement of boundary between salty and fresh in (qp) aquifer

\begin{tabular}{|c|c|c|c|c|}
\hline \multirow{2}{*}{$\begin{array}{l}\text { Order } \\
\text { number }\end{array}$} & \multirow{2}{*}{ Study site } & \multirow{2}{*}{ Move direction } & \multicolumn{2}{|c|}{ Movement prediction results } \\
\hline & & & Distance, $\mathrm{m}$ & Speed, $\mathrm{m} /$ year \\
\hline 1 & $\begin{array}{l}\text { VinhTuy- BinhGiang } \\
\text {-Hai Duong }\end{array}$ & Southeast-Northwest & 140 & 9.3 \\
\hline 2 & $\begin{array}{l}\text { Cam Son- Cam Giang } \\
\text {-Hai Duong }\end{array}$ & Northeast-Southwest & 88 & 5.9 \\
\hline 3 & $\begin{array}{l}\text { Ho town -ThuanThanh } \\
\text { - BacNinh }\end{array}$ & South-North & 40 & 2.7 \\
\hline
\end{tabular}

The results of this study show that groundwater (qp) in the study area is likely to be salinized, It is necessary to continue to observe and study measures to prevent salinity intrusion in the following directions: study rational exploitation solutions, building walls at the boundary between salty and fresh, Construction of artificial additions to underground water or salt water pumps near the boundary between salty and fresh...

\section{Division and zoning of hydro-geochemistry}

\subsection{Hydro-geochemistry division vertically}

Hydro-geochemistry division is the change in the mineralization of groundwater in the geological section from the top down [4]. Decreasing of TDS is normal of hydrogeochemistry. Increasing of TDS is invers of hydro-geochemistry

I. K. Zaixev [1, 4] has divided into three main zones: Zone A contains fresh water (TDS
$<1 \mathrm{~g} / \mathrm{l}$ ); Zone B contains saltwater (TDS 1 $35 \mathrm{~g} / \mathrm{l}$ ); Zone $\mathrm{C}$ contains salt water (TDS $>35 \mathrm{~g} /$ 1).

N. I. Tonstikhin $[1,4]$ has divided into 6 types of hydro-geochemical sections as shown in Figure 4.

According to research results of Nguyen Van Dan [4] many regions in our country, including research areas, do not have zone C. Based on the variation of the two zones $\mathrm{A}$ and $\mathrm{B}$, it is possible to divide the study area into 3 types of hydrogeochemistry sections: I, II and V to map the zoning of the hydro-geochemistry.

\subsection{Zoning of hydro-geochemistry}

The study area is divided into 3 regions with different hydro-geochemistry zoning corresponding to the above three types of hydrogeochemistry sections. On the zoning map, the symbol of the region is taken from the hydrogeochemical type (Figure 5).
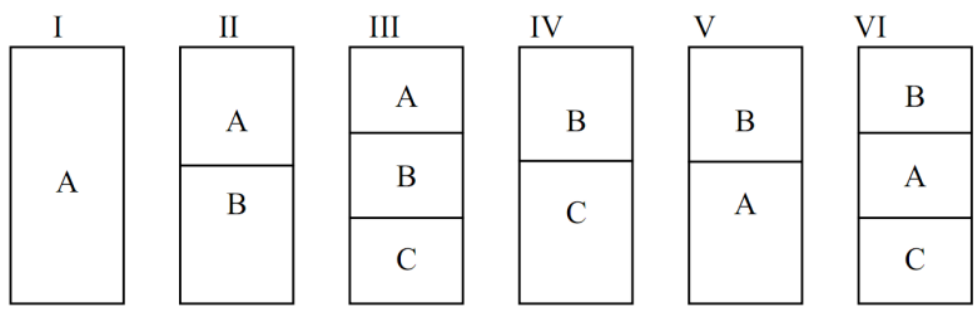

Figure 4. Types of hydro-geochemical sections according to N.I.Tonstikhin 


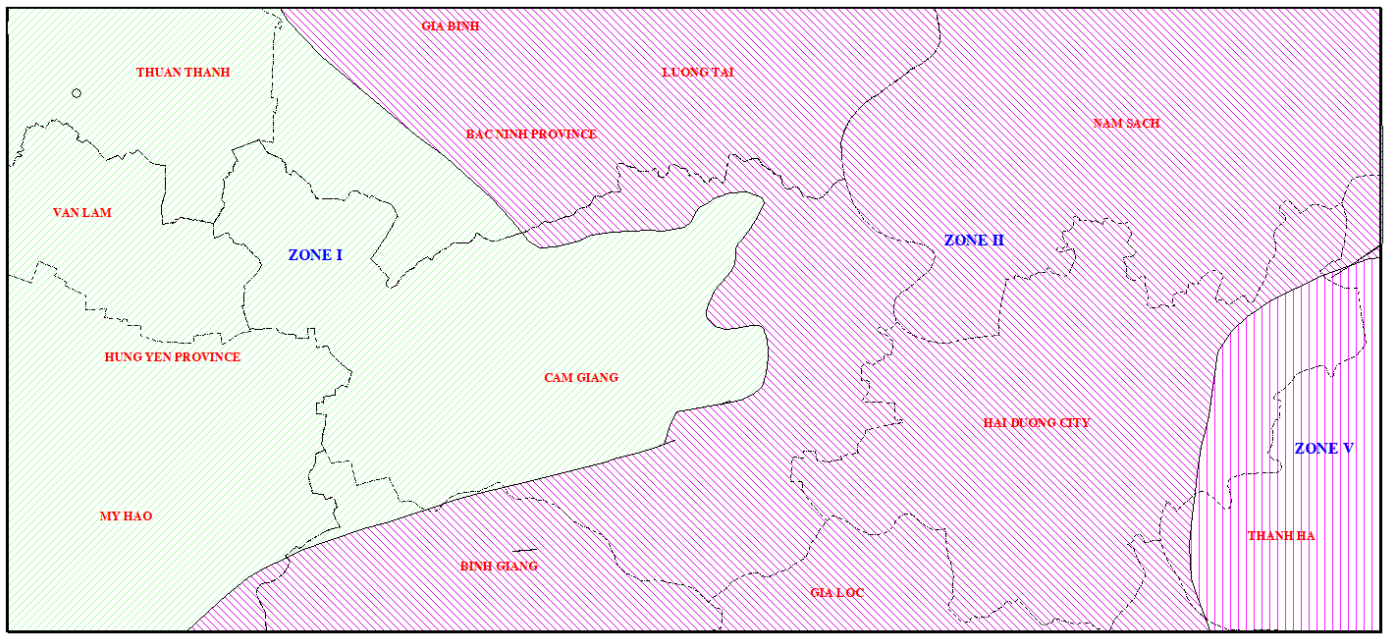

Figure 5. Map of hydro-geochemical zoning in Hai Duong urban area

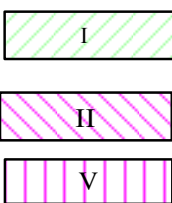

Zone I: all aquifers contain in section fresh water

Zone II: the (qh) aquifercontains fresh water, (qp) aquifer and (n) all contain saltwater

Region V: (qh) and (qp) contain saltwater, (n) aquifer contains fresh water

Zone I: In the cross section, all aquifers contain fresh water, distributed in My Hao and Van Lam districts of Hung Yen province; Thuan Thanh of Bac Ninh Province and part of Cam Giang District of Hai Duong Province. There are 3 aquifers: (qh), (qp) and (n) which contain fresh water.

Zone II: In the top down cross section, (qh) aquifer contains fresh water, (qp) and (n) aquifers all contain saltwater distributed in Luong Tai district of Bac Ninh province and part of Cam Giang district, Nam Sach district, Hai Duong province, in this case, mineralization of (qp) aquifer is greater than (n)the aquifer.

Region $V$ : In the section, (qh) and (qp) aquifers contain saltwater, (n)the aquifer contains fresh water, distributed in part of Hai Duong City and Thanh Ha District of Hai Duong Province.

Zone I: has a type of normal hydrogeochemistry, have top-down recharge. Zone $\mathrm{V}$ hasinvers of of hydro-geochemistry, (n) aquifer have remote power supply similar to the Hai Hau area of Nam Dinh province, but where is the recharge zone? It must be researched. Zone II has both normal and invers of hydrogeochemistry, the (n) the aquifer has both remote and top-down.

\section{Conclusion}

- In Hai Duong city, there are 3 aquifers :(qh), (qp) and (n), of which (qp) and (n) aquifers are meaningful centralized water supply.

- Water quality characteristics of all three the aquifers are high in TDS, iron, manganese and nitrogen compounds, of which the salinity of the three aquifers is 22 to $64 \%$ of the aquifer area. TDS be increased means ancient sea water was washed salty, there is currently a risk of salinization due to unreasonable exploitation; high content of iron, manganese, and nitrogen compounds indicate contaminated water; 
- The aquifers are at risk of salinization, which is predicted by the numerical model of reservoir (qp) aquifer until 2030. Under the current mining conditions, the rate of salinity intrusion can reach from 2.7 to $9.3 \mathrm{~m} /$ year;

- The study area has 3 zone corresponding to 3 types of hydro-geochemistry: Zone I - All aquifers in the transect contain fresh water; Zone II - The top aquifer contains fresh water, 2 aquifers below contain saltwater and zone V- 2 upper aquifers containing saltwater, aquifer below contain fresh water. Zone I has a type of normal hydro-geochemistry, Zone $\mathrm{V}$ has hasinvers of of hydro-geochemistryand Zone II has both types hasinvers of hydrogeochemistry./.

\section{References}

[1] Nguyen Kim Ngoc et al. (2005). Geochemical chemistry: Transportation Publishing House Company Limited. Hanoi 2005, pp. 32-38 and 106108.

[2] Hoang Van Duy (2017). Study on the hydrogeochemical characteristics of Hai Duong urban area, Master thesis, Archives of University of Mining and Geology, pages 40-96.

[3] Nguyen Van Dan, Nguyen Thi Dung (2004). Groundwater contamination in Hanoi, Journal of Geology A / 280-1-2 / 2004, Hanoi 2004, pp. 48-57.

[4] Nguyen Van Dan et al. (2015). Geological, hydrological and geochemical features of coastal areas in Vietnam, Journal of Marine Science and Technology, 334-340, Hanoi, pp. 334-340.

\title{
Đặc điểm thủy địa hóa và tính phân đới của chúng khu vực đô thị Hải Dương
}

\author{
Nguyễn Văn Đản ${ }^{1}$, Hoàng Văn Duy ${ }^{2}$, Văn Thùy Linh ${ }^{3}$, Trần Duy Hùng ${ }^{4}$ \\ ${ }^{1}$ Hội Địa chất Thủy văn Việt Nam, Số 10, Trần Cung, Cầu Giấy, Hà Nội, Việt Nam \\ ${ }^{2}$ Liên đoàn Quy hoạch và Điều tra Tài nguyên nước miền Bắc, Số 10, Trần Cung, Hà Nội, Việt Nam \\ ${ }^{3}$ Viện Tài nguyên, Môi trường và Phát triển bền vũng, 114 Trần Duy Hung, Cầu Giá́y, Hà Nội, Việt Nam \\ ${ }^{4}$ Cục Quản lý Tài nguyên nước, 10 Tôn Thất Thuyết, Cầu Giấy, Hà Nội, Việt Nam
}

Tóm tắt: Khu vực đô thị Hải Dương bao gồm thành phố Hải Dương và phụ cận với diện tích khoảng $500 \mathrm{~km}^{2}$, nằm ở trung tâm Đồng bằng Bắc Bộ có 3 tầng chứa nước chính là (qh), (qp) và (n). Mức độ chứa nước của tầng ( $\mathrm{qp}$ ) và $(\mathrm{n})$ khá phong phú có ý nghĩa cung cấp nước tập trung, song chất lượng nước kém và không đồng đều đã làm hạn chế ý nghĩa cung cấp nước. Những vấn đề cần cần quan tâm về chất lượng nước khu vực nghiên cứu là độ tổng khoáng hóa (TDS), hàm lượng sắt, mangan và các hợp chất nito của nước tăng cao. Phần lớn diện tích của 3 tầng chứa nước đều bị mặn với diện tích từ 22 đển $64 \%$ tổng diện tích phân bố tầng chứa nước. Tầng chứa nước (qp) có thể bị nhiễm mặn, dự báo đến 2030 , tốc độ nhiễm mặn theo chiều ngang có thể đạt từ 2,7 đến $9,3 \mathrm{~m} / \mathrm{năm}$. Khu vực nghiên cứu có 3 kiểu mặt cắt thủy địa hóa: kiểu I- tất cả các tầng chứa nước trong mặt cắt đều chứa nước nhạt; kiểu IItầng (qh) trên cùng chứa nước nhạt; tầng $(\mathrm{qp})$ và $(\mathrm{n})$ bên dưới chứa nước mặn, trong đó nước của tầng (qp) mặn hơn tầng $(\mathrm{n})$ và kiểu $\mathrm{V}$ - tầng (qh) và (qp) bên trên chứa nước mặn, tầng $(\mathrm{n})$ bên dưới chứa nước nhạt. Kiểu I có tính phân đới thủy địa hóa thuận; kiểu $\mathrm{V}$ có tính phân đới nghịch; Kiểu II có cả tính phân đới thủy địa hóa thuận và nghịch.

Tù khóa: Chất lượng nước, nhiễm mặn, phân đới thủy địa hóa, tầng chứa nước. 